${ }^{11}$ Burton, S. W. (1987) The psychiatry of HIV infection. British Medical Journal, 295, 228-229.

${ }^{12}$ Navia, B. A., Jordan, B. D. \& Price, R. W. (1986) The AIDS dementia complex: I. Clinical features. Annals of Neurology. $19,517-524$.

${ }^{13}$ Hardy, A. N., Rauch, K., Echenberg, D., Morgan, W. M. \& Curran, J. W. (1986) The economic impact of the first 10,000 cases of acquired immune deficiency syndrome in the United States. Journal of the American Medical Association, 255, 209211

14Johnson, A. M., Adler, M. W. \& Crown, J. M. (1986) The
Acquired Immune Deficiency Syndrome and epidemic of infection with human immuno-deficiency virus: costs of care and prevention in an inner London district. British Medical Journal, 293, 489-492.

${ }^{15}$ ADLER, M. W. (1987) Care for patients with HIV infection and AIDS. British Medical Journal, 295, 27-29.

${ }^{16}$ Cunningham, D. \& Griffiths, S. F. (1987) AIDS: Counting the cost. British Medical Journal, 295, 921-922.

${ }^{17}$ AmERICAN Geriatric SOCIETY (1987) AIDS, aides and aging. Clinical Report on Aging, 1, 2.

\title{
North East Thames Regional Health Authority \\ Consultant Appointments in Psychiatry for 1987
}

Dr G. S. Ibrahimi, Consultant in Psychogeriatrics in Haringey \& Hampstead, 22 January 1987.

Dr J. Katwala, Consultant in Child Psychiatry in Southend, Essex, 17 February 1987.

Dr M. K. Seneviratana, Consultant in Mental Handicap in Mid Essex, 1 April 1987.

Dr E. C. Johnson-Sabine, Consultant in Mental Illness in Haringey, 9 June 1987.
Dr J. W. Coid, Consultant in Forensic Psychiatry in Haringey, 1 September 1987.

Dr S. Isaacs, Consultant in Child Psychiatry in Waltham Forest, Essex, 1 September 1987.

Dr J. P. Meehan, Consultant in Mental Illness in Waltham Forest, Essex, 2 November 1987.

The Editors would welcome information about recent consultant appointments from other Regional Health Authorities.

\section{New Publication}

Behaviour Problems in Mental Handicap: An Annotated Bibliography 1970-1985. By Kenneth Day, Joyce Hamilton and Paul Smith. London: Gaskell (Royal College of Psychiatrists). 1988. Pp 144. £7.50.

The purpose of this bibliography is to present the literature in an orderly fashion, and in an annotated form, which will be of use to practitioners, service planners, those running professional training courses, and researchers.

It is concerned only with behaviour problems: mental illness superimposed on mental handicap, and delinquency, are not covered. There is a brief list of recent reviews of autism: articles on that subject are included where there are associated mental handicap and behaviour problems. 